\title{
Allen Tate's Agrarianism: a Defense of Allegiance
}

\author{
Assist. prof. Dr. Nadia Ali Ismail \\ University of Baghdad /College of Languages- Department of English
}

Submission: 244 at $26 \backslash 5 \backslash 2016$

Abdullah: 402 at $16 \backslash 6 \backslash 2016$

\section{$\underline{\text { Abstract: }}$}

Allen Tate (1899-1979) was born in Kentucky .As a Southerner he was unwilling to be like his people who were unaware of their imperfections. He realized that lack of belief in tradition which was the illness of the modern mind. It turned life to hell with a variety of tortures. Hence his agrarianism was a call to the Southerners to retreat to their tradition.It was a revolt against industrialism as an enslaving power, a destroyer threatening the very existence of human society. His agrarianism proved to be an image of life man should desire, a life imbued with tradition and belief; tradition in its historical and religious sense shapes the spirit of protest in his poetry. It is a protest against the kind of life modern man attached himself to, which dehumanized him resulting in spiritual fragmentation. Tate did what none of his fellow Agrarians attempted, to turn Agrarian concerns inward, a quest for identity, for spiritual roots and affirmation. This is what makes his agrarianism a defense of personal allegiance, besides its historical, social and religious implications.

Key words: Agrarianism. Southerners. protest. tradition. religion. Industrial.

\section{الحركة الزراعية لدى الان تيت : دفاع عن الولاء أ.م.د. نادية عابي اسماعيل}

\section{جامعة بغداد / كلية الغات - قسم الغة الانكليزية}

الملخص:

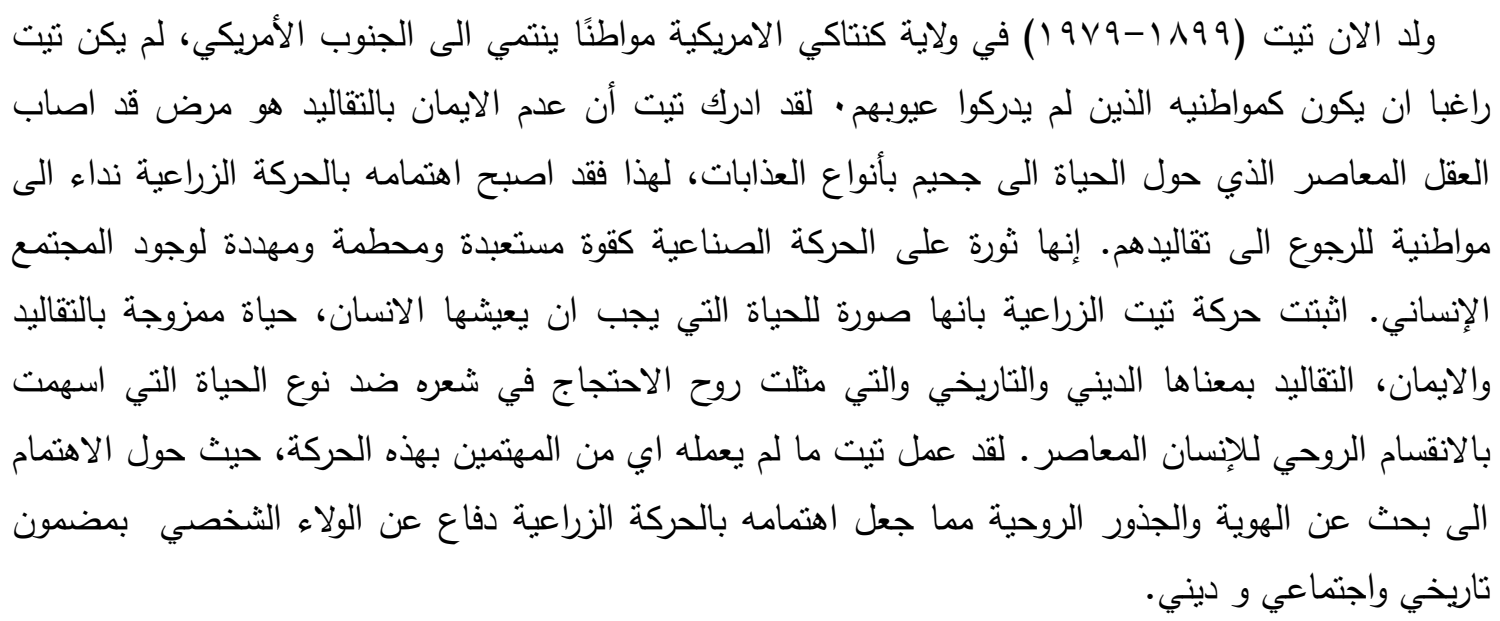




\section{The Agrarians}

The Agrarians were the inheritors of the Fugitives who promulgated the Agrarian movement and constituted the impetus of what came to be known Southern literary renaissance. ${ }^{1}$ These poets, Allen Tate wrote:

started with open-minds- that is, with the simple aim of writing poetry . But after five or six years it became clear that quite unconsciously they were fostering a sectionalist spirit . ${ }^{2}$

The cause behind this change was mainly the famous trial of J.T. Scopes which made them aware of their Southern heritage. ${ }^{3}$ Donald Davidson, one of the Agrarian writers, in Southern Writers in the Modern World, comments on this change, saying:

with the jeering accompaniment of large- scale mockery directed against Tennessee and the South broke in upon our literary concerns like a mid night alarm .... We rubbed our eyes and looked around in astonishment and apprehension . Was it possible that no- body in the South knew how to reply to a regular rhetorician like... Mencken ?... how difficult it was to be a Southerner in the twentieth Century, and how much more difficult to be a Southerner and also a writer. ${ }^{4}$

Besides the Scopes' trial, the disillusionment and the moral decay in the aftermath of the First World War, the economic crisis which began with the Stock Market Crash of the 1929 and culminated in the Great Depression years, helped to start a boiling controversy and a reconsideration on the part of Southerners who realized that the South was being split by the new economic forces. The new business tempo of the New South invaded even the towns, putting aside the Old South World and embracing the new profit of the Northern industrialization with its direct investment in the South. ${ }^{5}$ The result of Southern reconsideration was a book entitled I'll Take My Stand: The South and the Agrarian Tradition ( 1930 ), an- Agrarian manifesto which came to mark the depth that the Fugitives got as they shifted their creative energy to social and cultural criticism. ${ }^{6}$

The Agrarians saw a South which was beginning to emulate the ways of Northern industrial society. This means, the South in its way to gain material profits was to turn its back on a life that was agrarian, religious, and traditional which emphasized man's relation to nature. ${ }^{7}$ A kind of life which is a "mere mechanization, " as John Ransom ( 1818 -1974 ) describes it. ${ }^{8}$ Hence in the "Statement of Principles" they tended to support a Southern way of life against what may be called the American or prevailing way ; and all as much as agree that the best terms in which 
to represent the distinction one contained in the phrase, Agrarian Versus Industrial . ${ }^{9}$

The Agrarians showed both rejection and disillusionment in their protest against industrialism. They rejected industrialism because the factory system "subtracts the dignity from human labor and the aesthetic value from the product,"as Ransom says. ${ }^{10}$ Equally they were protesting against the dehumanizing and disintegrating effect of scientific and industrial progress. In the introduction to their symposium they indicated their hostility to science:

The capitalization of the applied sciences ...

has enslaved our human energies to a degree now clearly felt to be under scene.$^{11}$

Industrial and scientific progress turn men into mere functions, specialists rather than "men of the world" with "balanced character." ${ }^{12}$ Man is turned to a " robot." ${ }^{13}$ This is exactly what makes the Agrarians see the industrial North as a savage place where men are reduced to "adolescents" and life into a "jungle" of conflicting impulses. ${ }^{14}$

However, the Agrarians were not protesting against industry in its proper role, but as a tyrant enslaving power, a destroyer threatening the very existence of human society.$^{15}$ This is exactly what turned progress into a controversial essay in I'll Take My Stand entitled "Reconstructed but Unregenerate." One can detect that the Agrarians, like other Southerners in the 1920's, seek both change and remain themselves, to preserve what they consider a valuable cultural inheritance endangered by industry. That is, they have the desire to reconcile tradition and progress, to be reconstructed but unregenerate, as Ransom says.${ }^{16}$ Or as Stark Young, another Agrarian, puts it "We accept the machine, but create our own attitude toward it." 17

Closely related to their rejection of industry, is their disillusionment with democracy. They saw that the very basis of democracy was threatened by the defeat of the South during the Civil War. ${ }^{18}$ This is what marked the South as "the Achilles heel of American democracy." ${ }^{19}$ They saw the South as a mature old society, a contribution of Western civilization. Hence they emphasized a return to cultural values rather than the material ones of the "immature" North. ${ }^{20}$ This explains their interest in the past, in pre-industrial Europe, in the Middle Ages which seemed to them to represent an ideal society. ${ }^{21}$ The Medieval community with its spiritual unity provided man, they thought, with leisure necessary for spiritual cultivation. $^{22}$

However, such an interest in the past did not mean that the Agrarians were trying to reverse the clock. They did not want to restore what is unrestorable: "I never thought of Agrarianism as a restoration of 
anything in the Old South," Tate says "I saw it as something to be created ... not only in the South ... but in the moral and religious outlook of Westernman." ${ }^{23}$ The Agrarians took the Old South as a symbol that would bind together their disparate values. For them to know the past was to understand the present . ${ }^{24}$ The Old South disdained all forms of disruptive progress which threatened its tradition, hence progress was considered "Satanic." ${ }^{25}$ In an attempt to define what Louis Decimus Rubin believed the Old South represented to the Agrarians, he writes:

It was the image of a society that very likely never existed, but one that should have existed, in which men could live as individuals and not as automations, aware of their finiteness and their dependence on God and nature. ... In contrast to the hurried, nervous pace of life in modern cities, the agrarian South was the image of a society in which human beings could live serenely and harmoniously. Not dominated by lust for money and power, they could be free of the tension and harassment of the modern industrial community. $^{26}$

The harmonious life that Rubin praised could be seen in the relationship between the whites and the slaves. Despite the white supremacy in the Old South - the Agrarians saw that the slaves did not suffer at all. Only the theory of slavery, and not its practice was monstrous. ${ }^{27}$ The Negroes were not depicted as objects of human exploitation. Tate had suggested that the Negro slave of the Cotton Kingdom was better than the modern wage- earner because he could never join the rank of the unemployed. ${ }^{28}$ The dominance of the whiteman over the Negro created a sense of brotherhood which the Agrarians saw similar to the Greek concept of democracy. ${ }^{29}$ This could be seen in the character of the gentleman who treated the Negroes kindly because he cared for his honour rather than money which was beneath his concern. ${ }^{30}$

What is important about the Old South was that its traditional society took agriculture as a major form of employment. Property was a "thing to -be-used," rather than "to -be -sold." ${ }^{31}$ This is exactly what turned agriculture into a satisfying way of living both to man's reason, supplying him with material product, and his sensibilities, providing him with free and delicate aesthetic experience. ${ }^{32}$ The contrast was offered by the industrial society where the main duty of man was to increase production. ${ }^{33}$

Being an agricultural society the Old South took its strength from the earth from which it received a healthy moral fibre, a proper relation with God. As Andrew Lytle puts it:

It is in fact impossible for any culture to be sound 
and healthy without a proper respect and proper regard for the soil.$^{34}$

The culture of the soil which the Agrarians advocated was based on the philosophy of Thomas Jefferson. He believed that freedom and equality could be maintained only in an agricultural society where property could be distributed equally that all men might possess a little. ${ }^{35}$ Such a culture was based on subsistence farming as opposed to commercial farming. Its ideal was a self-sufficient farmer providing for all his family's needs, a free man who would not seek profits, but a living. ${ }^{36}$ Hence the farmer would be his own carpenter, road maker, meat packer, wood cutter, gardener, nurseryman and dairyman. ${ }^{37}$

In returning to the land man would sense the grandeur and mystery of nature and ultimately religion would flourish, as Donald Davidson puts it: "the education of nature ... must finally be a religious education." ${ }^{38}$ But in an industrial society religion had been destroyed in its belief that man was perfectible. Hence in their "Statement of Principles" the Agrarians assert that:

Religion can hardly expect to flourish in an industrial society. Religion is our submission to the general intention of a nature that is fairly inscrutable; it is the sense of our role as creatures within it. But nature industrialized...is no longer nature but a highly simplified picture of nature. ${ }^{39}$

Man needs God to provide him with spiritual means to cope with the precariousness of life. When science deprived man of God in its consistent search for factual truth, he would find himself in a spiritual waste land. $\mathrm{H}$ e would surrender grace, virtue, humanity itself. Hence comes the protest of the Agrarians to make people aware that "now religion is not religion at all, but a purely secular experience." ${ }^{40}$ Man was turned to be partial man:

a half man in a half society and if he has religion

at all that is a 'half religion,' which ignores

mysticism in favor of the partial truths of ... 'particularity.' 41

Agrarianism was not to be taken as a guide to political action or a treatise on economics but a defense of noble human values, and a protest against the instincts of greed and selfishness which threatened the survival of civilized community. It is a philosophy that reaffirms man's spiritual need. It is an image of what good life should be. Thus the Agrarians are champions of a specific social ideal in sharp contrast with the industrial world. Looking critically at the advantage of becoming a New South, their symposium marks a call to Southerners retreat to their tradition. The 
most representative poet who believed firmly in the philosophy of Agrarianism is Allen Tate.

\section{Allen Tate (1899-1979)}

\section{Chapter Two}

Allen Tate was born in Kentucky in 1899, the youngest of three boys. Owing to his weak health he was close to his mother who spent most of her time with him . Eleanor Parke Custis Varnell, a formidable mother, traced her origins to the Virginia Tidewater aristocracy. ${ }^{42}$ Her family had been a prosperous slave holder in Fairfax county and had a distant relationship to George Washington . ${ }^{43}$ She was proud of her family, especially her father who fought at Gettysburg in Picketts charge. ${ }^{44}$ She used to give her boys a mythological account of their genealogy, besides taking them to their plantation, "Pleasant Hill," which was destroyed by the Yankees in $1861 .{ }^{45}$ Thus Tate's mother played an important role in the formation of his Southern identity in drawing his attention to its history.

Due to her unstable marital relationship she used to avoid her husband by taking her children with her from one place to another in a kind of expedition financed by gradually selling off inherited land. ${ }^{46}$ Tate grew angry about the unsettled circumstances of his childhood. He was like an "orphan," as Thomas A. Underwood describes him. ${ }^{47}$ "What I remember most about my boyhood," Tate once told an interviewer, "was being moved around." ${ }^{48}$ Until he entered college he rarely stayed more than a few years in one place. Most of the places were Midwestern or Northern rather than Southern, yet this stimulated his interest in Southern Agrarianism and his hatred to Northern industrialism.

The cultural division between the South and the North could be seen in another way in Tate's mind. The image of the Old South represented by his aristocratic mother and the New South represented by his father. A middle- class man who was never a do- well businessman whose fortunes ebbed steadily causing Tate to speak of him as a cause of humiliation to the family. ${ }^{49}$

As he grew more mature as a poet, Tate realized his need to be aware of his time. As a Southerner he was unwilling to be like his people both blind and benign. He saw the tragedy of his people: though they were gracious, they were not so intelligent because they were unaware of their imperfections, as he says in an article entitled "Last Days of the Charming Lady." 50

He realized that lack of belief in tradition, which he observed as the "deep illness of the modern mind" was the problem ${ }^{.51}$ This turned life in modern society to hell with a variety of tortures. Tate, like Dante, did not 
spare himself from this hell. He was trapped in the modern dilemma and became a living dead. In a letter to Davidson (1929) Tate wrote:

We are all at present doomed to live a harrowing life, ... and it may or may not be more harrowing than the lives of all men everywhere who have tried to find some ultimate discipline of the soul. ${ }^{52}$

Tate argues that tradition should be the core of one's awareness as "it gives us fixed procedures that we rely on the larger pursuit of the good life. ${ }^{53}$ It is for him not an abstract concept, but a meaningful concrete experience. In a letter to his fellow Agrarian, John Gould Fletcher (1930), he defines tradition as "an image of concrete living fills the minds of enough people to constitute a basis of action." ${ }^{54}$

In an essay entitled "What is a Traditional Society?" ( 1936 ) he defines it as one which depends on agriculture because the land is the form of property which involves not only material welfare, but moral standards. ${ }^{55}$ The fields educate man, make him aware of his human limitation and his dependence on powers beyond his control that is the essence of religious belief. In a traditional society man achieves:

a unity between his moral nature and his livelihood, ... He dominated the means of life: he was not dominated by it .... In order to make a livelihood men do not have to put aside their moral natures. Traditional men ... are making their living all the time, and affirming their humanity all the time. The whole economic basis of life is closely bound up with moral behavior, and it is possible to behave morally all the time. ${ }^{56}$

When this disappears, the immediate alternative is called "untraditional society." ${ }^{57}$ In this context man is deprived of moral unity because the structures of his environment are founded on "Finance - capitalism" which Tate describes as: a system has removed men from their responsible control of the means of a livelihood, is necessarily hostile to the development of a moral nature. ${ }^{58}$

Property and moral responsibility are separated from one another, and the result is a general fragmentation of personality, an appropriate contrast to his vision of the rural life:

in ages which suffer the decay of manners, religion, morals, codes ... means are divorced from ends ... society from the individual, religion from moral agency ... poetry from thought ... There is literally no end to this list of dissociations because there is no end 
... to the fragmenting of the western mind.$^{59}$

Tradition for Tate takes two forms: history and religion. History for him is not merely events come down to inheritors, rather it is a code of values which functions as a guide for living and a basis for artistic creation. ${ }^{60}$ That is, it helps to understand the present and to achieve moral stability and spiritual certainty. "My attempt," Tate told Davidson, "is to see the present from the past, yet remain immersed in the present and committed to it." ${ }^{61}$

Religion is the other side of tradition for Tate. It is a "profound conviction about the way life should be lived." ${ }^{62}$ It is for him culture, a "deep unity of mind" with other members of society. ${ }^{63}$ Tate emphasizes the need for religion as "the sole technique for validating values "to achieve a harmonious adjustment between life and thought which could exist only in a stable society. ${ }^{64} \mathrm{He}$ observes that religious faith is destroyed by the use of reason, the instrument of abstraction and science. ${ }^{65}$ Abstraction debases human sensibility, turning the mind into a mere machine and blocks it from apprehending concrete experience Tate considers "the death of religion no less than the death of anything else." ${ }^{66}$ In his essay in I'll Make My Stand entitled "Remarks on the Southern Religion" ( 1930 ) which he rewrote under the title of "Religion and the Old South" in_Essays of Four Decades ( 1971 ), Tate condemns the Southerners as "pretentious" who fail

To re-establish a ... self - contained and essentially spiritual life. ... They had a religious life, but it was not enough organized with a right mythology.. In fact, their rational life was not powerfully united to the religious experience, as it was in medieval society ....

They elaborated no rational system whatever, no full -grown philosophy; so that, when the post - bellum temptations of the devil... confronted them, they had no defense. ${ }^{67}$

For Tate the South failed to develop the dogma of a true religion. It has only the "trading religion" 68 against which he was protesting,

The South would not have been defeated had she possessed a sufficient faith in her own kind of God .She would not have been defeated ... had she been able to bring out a body of doctrine setting forth her true conviction. ${ }^{6}$

In a word, tradition in its historical and religious sense shapes the spirit of protest in Tate's early and later periods, as the following sections will reveal. 


\section{Chapter Three \\ Protest in the Early Poetry of Tate}

Tate's early protest as an Agrarian mainly covers the twenties and thirties of his poetic products. Tate extends the problem of tradition, beyond that of the Southern heritage to that of Europe, giving his poems a wider scope. In a poem entitled "Causerie" (1927), for example, modern man's present disintegration is vividly illustrated. It takes the form of a reverie by one who could not sleep because he lost touch with the past, the standard which helps him understand his restless anxieties. $\mathrm{He}$ wonders at the way heroes in the past behaved. They were not harried with uncertainty. They could sleep and be active "who got out of bed at four to vex the dawn." ( 5$)^{70}$ But the heroic past seems stagnant and vague "Where now the antique courtesy of your myths / Goes into Sleep under a still shadow ? ( $105-106)$. The past is neglected. It counts for no one but insects "Blood history is the murmur of grasshoppers" ( 33). What is left of the past is only remnant, just like the "Pleasant Hill,"Tate's mother's Virginia house. Hence he wonders:

Where is your house, in which room stands

your bed?

What window discovers your insupportable

dreams?

In a lean house spawned on backed

limestone

While talking mainly of history, Tate includes religion as well. In the present time religion is of no help: it is a "wreck" and its image is cloudy and silent:

In Christ we have lived, on the

blood of Christ borne up,

Who now is a precipitate flood of silence,

We drenched wreck off an imponderable

shore,

A jugged cloud is our memory of shore.

$$
\text { ( 62-65) }
$$

In "Subway" (1927) Tate pictures human communications in the modern age like a "steel shell" leading to the "forestries of hell"

steel shell

Of angry worship, hurled religiously

Upon your business of humanity

In to the iron forestries of hell

$$
(15-8)
$$


Man turns to be an abstract, he moves blindly like an idiot:

I am become geometries, and glut

Expressions like a blind astronomer

Dazed, while the worldless heavens

bugle and reel

In the cold revery of an idiot.

$$
(11-14)
$$

Modern man's disconnection with the past, his alienation from the Southern history is artistically stressed in his reverie "Ode to the Confederate Dead" (1927). ${ }^{71}$ Here Tate protests against the loss of man's moral identity as he abandoned the values of the ante - bellum stable society to find himself whirled about in the chaos of unstable society of science and technology.

Tate explains in a letter to Davidson (1928) that the poem's theme is a "quest of the past" to which he feels an "acute" commitment. ${ }^{72}$ The result is complete spiritual exile from his heritage. He cannot recover the heroic past in "the fragmentary cosmos" of the present. Any reconciliation between them is impossible. Hart Crane comments on the poem, stressing that its theme is that of "chivalry, a tradition of excess ... active faith which cannot be perpetuated in the fragmentary cosmos of today. ${ }^{173}$

The character stands at the edge of a Confederate graveyard at dusk on a gray autumn day, haunted by the past. The conflict between the present and the past is presented in a series of images. He tries to picture the charging infantry, the soldiers who participated in the Civil War, but he could only focus his attention on the physical scene before him. All he could see are the leaves blowing about him "Seeing, seeing only the leaves / Flying, plunge and expire" ( $42-43$ ), symbolizing the futility of his attempt to restore the heroic past. ${ }^{74}$

The "falling leaves" reminds one of Homer's use of the leaf image in the ILiad as a reference to one's lineage. ${ }^{75}$ Here, the protagonist is in complete cut - off - ness from his roots. Besides, he "Hears the wind only," referring to his spiritual vacancy. He finds no meaning in what he sees, only the graves of dead soldiers. The natural desolation seen in the "setting sun" is only a reflection of his spiritual one, which results from his solipsism. ${ }^{76}$ In an essay entitled "Narcissus as Narcissus" ( 1938 ), written on the poem, Tate clarifies the theme of the poem, saying:

That poem is 'about' solipsism, a philosophical doctrine

Which says that we create the world in the act of perceiving it; or about Narcissism, ... that denotes the failure of human personality to function objectively in nature and society. ${ }^{77}$ 
The character's solipsism is clearly seen in the violent image of a jaguar. Instead of a youth gazing into a pool, a jaguar stares at a jungle stream and leaps to devour itself: ${ }^{78}$ "the jaguar leaps / For his own image in a jungle pool, his victim" ( $80-81)$. In a sense, Tate argues that the return to the past is a narcissistic self- destruction. The Southerner should accept some progress and reconcile old tradition with it.

He envies the strong conviction of the Confederates to fight oblivious of danger. His skeptical mind makes him consider their sacrifice as "unimportant shift of death" which does not come of heroism but they "hurried beyond decision" in the heat of battle. His inability to comprehend the "active faith," the heroism of the past is marked by the wall image of the cemetery. He remains at the gate incapable of entering the cemetery. The physical wall is an extension of the one within his mind.

In "The Man of Letters in the Modern World" ( 1952 ) Tate says : "Man is a creature that in the long run has got to believe in order to know and to know in order to do." ${ }^{79}$ To believe in absolutes helps man to know the meaning of his conduct and work accordingly. In the modern age rationalism blocked the way before man to have belief in absolutes. His mind grew sceptical and all absolutes for him turned to be illusory. This is clearly seen in the character of the poem. He could not comprehend the courage, the certainty, and belief of the Confederates. Such knowledge is beyond his conjecture. His knowledge is divorced from conviction and his action is without reason. He knows what animals know: "You know, who have waited by the wall, / Their twilight certainty of an animal" ( 27 -28). He is like the "blind crab," a creature with mobility, but no reason to direct it. He has energy, but he lacks the human purpose for it ${ }^{80}$

Modern man lost his creative imagination to transcend his sense knowledge. The twilight time reflects his confused, dazed, and illcontrolled mind. He is unable to see the real universe as whole, as ancient philosophers, Zeno and Paramides saw it. He can only see the apparent universe which is illusory. Hence he starts to brood idly at the tombstones. He imagines that he hears their shouts. The "Owl" sound fills him with "murmur of their chivalry." Suddenly he is hypnotized by the outward silence which engulfs, him and turns him into" mummy," motionless whereas the dead Confederates are free and active in theirs : Turns you like them, to stone,

Smothers you, a mummy, in time.

Waits mute speculation, the patient curse

That stones the eyes, 
What adds to his feeling of silence is the "hemlocks" which reminds him of the emptiness of modern life. They separate him from the living dead and compel him to remain in his own time. They intensify the juxtaposition between the Confederates and the man. The "hemlocks" are described as "crazy," referring to his mad world. ${ }^{81}$

At the end of the poem the character starts to meditate over death. If death, he says, is the only certainty, shall it be the way to escape his internal walls?

What shall we say who have knowledge

Carried to the heart? Shall we take the act

To the grave ? Shall we, more hopeful, set

up the grave

In the house? The ravenous grave?

He decides that such certainty cannot be applied to him in the modern world. He can neither find belief in life nor in death. Man is preoccupied with time, the only absolute for him. Time is pictured in the image of the "gentle serpent"

The shut gate and the decomposing wall:

The gentle - serpent, green in the mulberry bush,

Riots with his tongue through the hush -

Sentinel of the grave who counts us all.

$$
\text { ( } 86 \text {-90) }
$$

The serpent, says Tate in the above essay, is "the ancient symbol of time," but "time is also death." ${ }^{82}$ This is because time is the source of the lowest forms of life, "undifferentiated, half way between life and death." ${ }^{83}$ In this case he is thinking of his own spiritual death as he is living in the corrupted modern world.

Throughout the poem Tate uses numerous images with a melancholic sense. They indicate how pointless it is to restore what is unreturnable. Man is left with the memory of the dead confederates whose bodies feed the grass.

In "The Oath" ( 1931) Tate raises the question: "Who are the dead?/ Who are they living and the dead ?" (21-22). This question is asked by Tate's Agrarian fellow, Andrew Lytle, who was sitting in Tate's house meditating upon the picture of Tate's grandfather, Bogan, who fought in the Civil War. The whole place is filled with the spirit of the ancestors. But the wind, the chill, and the darkness belong to the present.

It was near evening, the room was cold

Half dark; ...

And powder-horn and Major Bogan's face

Above the fire in the half - light plainly said 
There's naught to kill but the animated dead

Being called I urged Lytle to the fire

We sat down evenly in smoky chill .

Till dusk seals the window, the fire grows bright,

And the wind saws the hill a swarm of bees.

We heard the darkness grapple with the night

$$
\text { (1-19) }
$$

The answer to the question comes when "Lytle turned with an oath - By God it's true!"( 30). The moderns are physically alive, but spiritually dead. The dead are more living than modern men who are described as the "animated dead."

In a more profound way Tate wrote "To the Lacedemonians" (1932) in which the speaker is a Confederate Veteran who finds his people in the modern age strange. They are blinded by the glare of science and technology: "people of my own kind my own / People but strange with a white light" ( 1-2) They are dehumanized, obsessed with motion and power only. Their eyes are "hard" ones, look one way, the way of profit: "the streets hard with motion / And the hard eyes that look one way" ( 34 ). They have eyesight, but they lack the human insight, "lack skill of interior mind, .../ Eyeless with eyesight only, the modern power." ( 40 , 87 ). They are cut off from the past: where have they, the citizens, all

Come from? They were not born in my father's

House nor in their fathers': on a street

But motion sired, not born; by rest dismayed

$$
\text { ( } 20-23 \text { ) }
$$

They have nothing worth living for. They "expect too much, do too little" ( 38). The Veteran does not see any difference between the Southerners and the Northerners: "All are born Yankees the race of men" (1. 84). They forget that all will end in death and "There is no civilization without death" (68).

The disparity between the past and the present is emphasized by the classical figure of Aeneas in "The Mediterranean" (1933), in which a wanderer makes a journey into the past, but in this poem it is the European past. His quest for tradition makes him leave his New World to the Old World, using Aeneas as an exemplar. It is through this "famous age / Eternal here yet hidden from our eyes" ( 21-22 ) he could grasp the true meaning of his present. The classical allusion to Virgil's Aeneas 
throws light on the degradation of modern man as he proved unwise to preserve his tradition: "We've cracked the hemisphere with careless hand !" ( 31) says Tate. Only with historical imagination may one return to the harmony of the classical hero.

This poem is originally entitled "Picnic at Cassis" which Tate wrote after he and Ford Madox Ford had gone for a picnic by the sea. ${ }^{84}$ When the picnickers ( Tate and Madox ) stood by the wateredge to eat their meal Tate was reminded by Aeneas and his men when arrived upon the shores of Italy.As a Southerner Tate sees the wreck of his forefathers' agrarian republic repeated in the plight of Aeneas. There is a clear juxtaposition between the two examples. When Aeneas and his men lost Troy they found Rome, a place of order which had a special meaning even for Southerners. ${ }^{85}$ Whereas the New Southerners who lost their Old agrarian world did not find a compensation . All they could find was bounteous soil but a "tired world." A world where people and adopted culture are exhausted. Thus Tate's journey ends:

Westward, westward till the barbarous brine

Whelms us to the tired world where tassels corn,

Fat beans, grapes sweeter than muscadine

Rot on the vine: in that land were we born

Aeneas is used in another poem entitled "Aeneas at Washington" (1933). He could be any of Tate's ancestors before the Civil War, or any person who devoted his energies to establishing a solid base for his life, to find himself in a totally broken and strange world.

Aeneas describes the defeated Troy: "That was a time when civilization / Run by the few fell to the many" $(8-9)$. Troy is like Kentucky for Tate. It is seen after the Civil War completely changed by the hurricane of the North. Everything is there, but a part. It lacks the peace which it used to enjoy:

I saw the thirsty dove

In the glowing fields of Troy, hem ripening And tawny corn, the thickening Blue Grass

All lying rich forever in the green sun.

I saw all things apart,

$$
(20-24)
$$

He is surprised because he could not recognize his city. It is not the ideal Southern City which he envisioned "I stood in the rain, far from home at nightfall ... / The City my blood had built I knew no more" $(32,34)$. He wonders about the reason behind building the city in the first place:

Stuck in the wet mire 
Four thousand leagues from the ninth buried city

I thought of Troy, what we had built her for.

$$
(37-39)^{86}
$$

With the end of the thirties Tate stopped writing on history as a form of protest against the sterility of the present, as the following section will show.

\section{Protest in Tate's Later Poetry}

\section{Chapter Five}

During the forties and early fifties Tate's protest took the form of a quest for religious faith. This trend in his poetry is not totally new, as an Agrarian as he earlier diagnosed the deep illness of modern man to be a problem of disbelief. Tate sees that modern man has lost his ability to think in a religious way, i.e., to see the presence of evil in the world ${ }^{87}$ as he observes in his essay "The Fallacy of Humanism "( 1944 ). He further argues that there is no substitute for religion. ${ }^{88}$ Thus he makes religion the core of his poetry during these decades.

In a letter to Davidson (1929), Tate expresses people's need for a "dogma," saying: "When morality lacks the authority of dogma, it becomes private and irresponsible." ${ }^{89}$ Thus, during this period, he became interested in the Catholic Revival. ${ }^{90}$ Seeing in Catholicism the origin of traditional religion, he was converted to it in 1950.

"Sonnets at Christmas" (1941) are two sonnets relating the poet's childhood experience with the religious problem. The first sonnet describes a character who cannot perceive the spiritual implication of Christmas. He is engulfed with silence:

But I must kneel again unto the Dead

While Christmas bells of paper white and red,

Figured with boys and girls spilt from,

Ring out the silence I am nourished by

$$
\text { ( } 11-14 \text { ) }
$$

In the second sonnet, the religious implications of his childhood experience is also not one of joy, rather of past sins which turn him to be conscious of his guilt. He remembers that he once told a lie that led to the whipping of a black boy. He feels that he is living in a nightmare and lacks the knowledge that could illuminate his way:

Am I untutored to the after -wit

Of knowledge, knowing a nightmare has no sound; 
Therefore with idle hands and head I sit In that December before the fire's daze Punished by crimes of which I would be quit.

$$
(10-14)
$$

In 1944 Tate wrote "Seasons of the Soul," a meditative poem with the disastrous implications of the Second World War. It was written during a period when Tate was involved in a search for religious belief. He was looking for spiritual salvation against the barbarism and savagery of Western man. The source of violence for Tate lies in alienation of human beings from one another, from nature, and more importantly from divine forces. The poem traces the disintegration of the soul. The same character progresses from one part to the other, hence all seasons are part of a single cycle.

The poet descends into his own hell as the epigraph says, which is taken from Dante's Inferno. It reads:

So I put forth my hand a little way,

And broke a branch let from a thorn tree tall;

And trunk cried out: "Why tear my limbs away."

$$
(31-33)^{91}
$$

The rending occurs when Dante and Virgil reach the seventh circle of hell, a wood where souls of lovers who committed suicide are punished, turned into a thorn tree where Harpies eternally feed.$^{92}$ The poet plucks a twig from the tree and the trunk shrieks "Why do you tear me ?" The epigraph starts the act of violence which the first of the seasons, "Summer" vividly illustrates. Tate uses it as a symbol of the ultimate political activity of violence, represented by war against human beings. It is the intellect which destroys the hearts and heads of man by evoking evil.

The summer of hell is not the summer of childhood. When the poet was an innocent child, he was far from the darkness of the present summer:

When was it that the summer

( Daylong a liquid light )

And a child, the new - comer, Bathed in the same green spray,

Could neither guess the night?

$$
\text { ( } 41-45 \text { ) }
$$

The present summer does not sustain, it destroys. The image of the "lion" is a clear reference to its savagery. The mind of man is debased from being "a hunting king" into a prey to "the lion's jaws," i.e., the "engaging jaws" of time.

The mind's tattering 
Blue of greedy claws?

Shall mind itself still live

If like a hunting king

It falls the lion's jaws?

( 6-10)

The dry atmosphere of violence is intensified by the "hot wind" which dries all signs of life. It is an echo of Dante's wind which blows the hot rain eternally on Brunetto Latini as a punishment for his violence against nature: ${ }^{93}$

The hot wind dries and draws

With circular delay

The flesh, ash from the ember,

Into the summer's jaws

(17-20)

War destroys even tradition, represented by the "Green France." It is no longer the active country. It is destroyed by wars "surprising jaws" represented by the "caterpillar," an image of mechanization. War debases even the past which is turned to be "invalid." It looks at the present with "tired eyes" and stands helpless because it cannot do anything to set it right. Tate concludes "Summer" with the image of a "Shell," a symbol of emptiness and narrowness. Man is living in hell where he lost his identity. Tate, unlike Dante, sees reason insufficient to lead man to salvation.

Tate's hell is extended from the present to the past which marks the second season, "Autumn." It is a hallucinating experience in which hell is the focus. Dreaming of the past marks his private hell which is only a microcosm of the public one. ${ }^{94}$ Such hell is as deep as a well and any attempt to recapture it is like descending into a well. The attempt is futile, it fills him with fear. It has the smell of autumn, that of isolation, and loneliness. It makes him, as autumn, neither living nor dead, a state in between, neither summer nor winter:

It had an autumn smell

And that was how I knew

That I was down a well:

I was no longer yours;

My lips were numb and blue,

$$
\text { ( } 61-65 \text { ) }
$$

It is worth mentioning that the season for Tate is originally linked with the element of earth, the solid ground on which to build something. ${ }^{95}$ Tate ( like other Southerners ) lacks this solid ground on which to build his present and future. He is rootless, cut off from his past. He cannot regain his past self. Neither his father nor his mother could recognize him.They look at him as if looking at a "faceless gloom": 
My father in a gray shawl

Gave me an unseeing glint

And entered another room!

I saw my down cast mother

Clad in her street -clothes,

Her blue eyes long and small,

Who had no look or voice

$$
\text { ( } 107 \text {-18) }
$$

The well he first found himself in is transformed into a cold and empty hall which is repeated in each of the six stanzas of the season. The hall is completely bare: no rug to cover the floor, the light is gray, thin, crumbling and dry. Nothing to attach, it is a complete emptiness:

And the gray light like shale

Thin, crumbling, and dry:

No rug on the bare floor

Nor any carved detail

To which the eye could glide;

In the third season, "Winter, "the violence is repeated in a different way. In its journey the soul is progressing towards an internal matter, that is, love. In the present time love is debased into a sub-human quality.It is nothing but physical violence. Since religion is as a dead man, it is left with the "pagan" concept of love. ${ }^{96}$ it is an echo of Dante's circle of Hell for gluttons and voluptuaries.

Eternal winters blow

Shivering flakes, and shore

Bodies that wheel and drop -

Cold soot upon the snow.

$$
\text { ( } 146-149)
$$

Man is imprisoned with what is animalistic :

In the centre of his cage

The pacing animal

Surveys the jungle cove

$$
\text { ( } 155-157)
$$

Hence comes Tate's invocation to Venus in her transcendental role, the role of Urania who stands for divine love. ${ }^{97} \mathrm{He}$ invokes her to return to the sea, the source of life, to give identity to her people who live in "eddying twilight." But the invocation is futile for love is degenerated. Returning to the sea is a sign of drowning not a life of baptism. ${ }^{98}$ She is the "Cold goddess" who "no longer bears for us / The living wound of 
love" ( 129 -130). Venus is connected with the "livid wound," which is turned to be a refrain in this part not the "living wound" of Christ.

Venus is linked with the "Shark," a fierce sea animal, instead of the "dove," with which she is usually linked. The dove brings peace and calmness which Venus in her present role does not provide:

A shark swift as your dove

Shall pace our company

All night to nudge and tear

The livid wound of love.

$$
\text { ( } 137-140 \text { ) }
$$

The inefficiency of Venus is seen in the image of "madrepore," a symbol of death in life. It seems to promise something which it does not offer. It is the "unaging oak, "which bears no leaf. When a branch of that tree is broken, a voice is heard, the voice of the "maimed" past speaks to the "maimed" present, as R. K. Meiners describes it. ${ }^{99}$

'We are the men who died

Of self - inflicted stratagem

Led to their suicide.'

$$
\text { ( } 172 \text {-174) }
$$

Finally comes "Spring," the last of the seasons. It is the season of rebirth, but here it comes without certain regeneration. The soul wonders if it is possible that "a new spring star" rises from the horror of war. It suspects its rising at a time when no one seems to be aware of. Such time is really the "chill." Modem man is left with uncertainty. The star is a false one, bringing false hope.

In time of bloody war

Who will know the time?

It is a new spring star

Within the timing chill,

Talking, or just a mime ,

That rises in the blood -

Without the human will?

$$
\text { ( 201-208) }
$$

Since "Seasons of the Soul" represents a quest for religious hope, it is ended with an invocation to "mother of silences." She could be the Virgin, a symbol of love and life. The last refuge for the harried souls who are fallen in a "barring cave," deep and dark. He asks for her kindness to men who are described as "blind," "lame," and slaves, deprived of free will.

Come, old mother, Save

Your sons who have gone down 
Into the burning cave

Come, mother, and lean

At the window with your son

And gaze through its highest frame

Upon the shirking scene

Where men, blind, go lame:

Then, mother of silences

$$
\text { ( } 221 \text {-230) }
$$

He asks her to speak to modern man, to make him hear her pious words, to listen to him while confessing his fear. He asks her to do something to these who "have begun to die" spiritually:

Speak, that we may hear;

Listen, while we confess

That we conceal our fear;

Regard us,

We have begun to die;

$$
(231-238)
$$

The poem ends with uncertainty: "Whether your kindness, mother, / Is mother of silences ( 239 -240). She seems mute and unresponsive.

The certainty which the soul is searching for is seen in the last of Tate's poetic achievement. It is entitled "Long Poem" ( 1952 -1953) which is a direct product of his conversion, confessional in tone, written openly out of faith. Only three parts are finished.

The first part is entitled "The Maimed Man" (1952). Here one can see a man of unbelief, but Tate writes it with a spirit of belief. As a young man, the poet meets a headless man. This figure is identified with the poet himself: a young man with errors. He looks at these errors with a new perspective of religious faith. He remembers them to heal his soul, to guide him to pray and fast:

Teach me to fast

And pray, that I may know the motes that tease

Skittering sunbeams are dead shells at last.

Then, timeless muse, reverse my time; unfreeze

All that I was in your congenial heal;

$$
(10-14)
$$

A direct boyhood recollection marks part II entitled "The Swimmers" (1953 ). Tate is going with five boys to swim. The idea of swimming is significant as it is linked with water, especially that Tate himself is described as putting "water on his brain." It is the water of baptism, purifying the soul. On their way to swim, they see a twelve - 
man posse with a lynched Negro's body. Obviously, the "nigger" represents Christ with his twelve disciples. .This incident becomes the prefiguration of Tate's understanding of the Passion. It also marks his knowledge of man's corrupt nature taking the Negro to be the object of suffering. Furthermore, it reflects Tate's social awareness of the injustice done to the Negroes, which does not conform to the Agrarian ideal picture of Negroes who are supposed to live in peace under white supremacy.

However, what he sees is only one "horseman" who takes care of the dead body.

A single horseman came at a slow lope

And pulled up at the hanged man's horny feet ;

The stranger tied to his pommel in a neat

Slip -knot. I saw the Negro's body bent

And straighten, as a fish - line cast transverse

Yields to the current that it must Subtend.

$$
\text { ( 60-66) }
$$

Originally the horseman represents Joseph of Arimathea who retrieves Christ's body from the Cross and takes it for burial. Tate recoils from the scene in horror, the horror of innocence first encountering evil, rather than from knowledge of its religious implication.$^{100}$ He wishes to recover this feeling "give me back the eye that looked and fled" (1.10). This nostalgia to boyhood innocence will be the base for the adult's religious awareness as he gained moral perspective. ${ }^{101}$

Part III of the poem entitled "The Buried Lake" (1953), is Tate's other dream of his childhood. He is looking for illumination. The first step is the rejection of carnal love, represented by a girl. The poet finds himself falling as he tries to embrace her. In a moment she turns into a" skull," indicating the negation of sensual love. What is physical is buried. After a period of wandering, the Virgin appears, a religious symbol which he accepts:

Lady coming,

Lady not going, come Lady come: I greet

Light choir upon my shoulder, speaking Dove

the dream is over and the dark expired

I knew that I had known enduring love.

$$
\text { ( } 104-26 \text { ) }
$$

Tate's Agrarianism proved to be an image of the life man should desire, a life imbued with tradition and belief. It is a protest against the kind of life modern man attached himself to, which dehumanized him 
resulting in spiritual fragmentation. His Agrarianism marks him as a whole man who looks for truth: human and divine. Thus he did not limit himself to history, believing that it gives him partial insight. It is God who gives genuine purpose since the problem of modern man is loss of belief, as he once told Ransom, the religious perspective is the imperative of both reference and belief for him.

Tate did what none of his fellow Agrarians attempted, to turn Agrarian concerns inward, a quest for identity, for spiritual roots and affirmation. This is what makes his Agrarianism a defense of personal allegiance, besides its historical, social, and religious implications. Thus Tate became a field commander of literary troops of the twenties and the thirties as he plays an important role in the tradition of protest of the time.

\section{NOTES:}

1- The Fugitives were a group of sixteen writers ( most of whom were associated with Vanderbilt University in Nashville ) and young men on their way to diverse careers in education, art and business. They began to meet from 1915 to 1928 reading their work and discussing matters of philosophy and literature. The group depended for its intellectual strength on: John Crowe Ransom, Donald Davidson, Robert Penn Warren, and Allen Tate. See Richard Gray, "The Nashville Agrarian" in Literature of Memory: Modern Writes of the American South (London: Edward Arnolds (publishers) Ltd, 1977, 40. For further details see Louise Cowan, The Fugitive Group (Baton Rouge: Louisiana State University Press, 1959), XVI.

${ }^{2-}$ John M. Bradbury, "The Beginnings," in The Fugitives: A- Critical Account (Chapel Hill: The University of North Carolina Press, 1958), 7.

${ }^{3-}$ Early in 1925 John Butler, a Tennessee legislator, introduced a bill prohibiting the teaching of evolutionary theories in the State schools. In the same year Scopes was asked by the American Civil Liberties Union to teach education to pupils to provoke the authorities to change the Law. Unwilling to do so at first, Scopes was persuaded by the Union to use the principles of the Old South to advance the interest of the New . Consequently, he was presented to a trial which turned into a show piece by H.L. Mencken, a prominent journalist in The Evening Sun who provided bail for Scopes. He bitterly attacked the South, charging Tennessee as a "joke State" and the South of Dayton as a "cultural desert." See Gray, "The Social and Historical Context," p.7 ; Fred C. Hobson, Jr., "Beyond Mencken : The Agrarians and the South" in Serpent in Eden :H.L. Mencken and the South (Chapel Hill : The University of North Carolina Press, 1974), 147 , 152; and Alexander Karanikas, "The Agrarian Movement" in Tillers of a Myth: Southern Agrarians as Social and Literary Critics (Madison: The University of Wisconsin Press, 1966 ), 7.

4 - Quoted by Hobson, Serpent in Eden, p. 150. In 1926 Allen Tate had written Ransom saying "we must do something about Southern history and the culture of the South". See Karanikas, "From Southern to Agrarian," 25. 
${ }^{5-}$ Bradbury, "The Beginnings," 8 - 9 .

6 - I'll Take My Stand is a collection of twelve essays. Most of the contributors were associated with Vanderbilt University under the inspiration of Ransom, Davidson and Tate. Other contributors were critic and novelist Stark Young, historian Frank Lawrence, former actor and novelist Andrew Nelson Lytle, psychologist and educator Herman Clarence Nixon, historian Frank Lawrence Owsley, biographer John Donald Walde, journalist Henry Blue Kline and poet John Gould Fletcher. See M. Thomas Inge," The Fugitives and the Agrarians" in Faulkner, Sut, and Other Southerners: Essays in Literary History (West Cornwall, ct: Locust Hill Press, 1992), 202.

${ }^{7-}$ Louis D. Rubin , Jr. and Robert D. Jacobs, eds. "Allen Tate : The Arrogant Circumstance,"in South Modern Southern Literature in Its Cultural Setting (Westport: Greenwood Press, Publishers, 1976 ), 231.

8- Paul V. Murphy,"The Survival of the South: The Agrarian Tradition, Southern Identity, and the Modern South," in The Rebuke of History: The Southern Agrarians and American Conservative Thought (Chapel Hill, NC: The University of North Carolina Press, 2001), 211.

9 - "Statement of Principles" in Twelve Southerners , I'll Take My Stand : The South and the Agrarian Tradition (Baton Rouge : Louisiana State University Press , 1977 ) , VII .

${ }^{10}$ Quoted by Karanikas, "Agrarian Economic Thought," 33.

11 "Statement of Principles," XI -XII.

${ }^{12}$ Gray, "The Nashville Agrarians," 44.

${ }^{13}$ Ibid., 48.

${ }^{14}$ Ransom, "Reconstructed but Unregenerate" in I'll Take My Stand, 4 - 5.

${ }^{15}$ Herman Clarence Nixon,"Whither Southern Economy" in I'll Make My Stand, 58.

${ }^{16}$ Ransom, "Reconstructed but Unregenerate," 5.

${ }^{17}$ Stark Young, "Not in Memoriam, but in Defense" in I'll Take My Stand , 355. Historian Stringfellow Barr who could not realize fully the Agrarians' spirit of protest wrote in the Virginia Quarterly Review that the Agrarians "ought never to Cry ' I'll Take My Stand' but ' Sit Down and Think'."He believed that the South should welcome industry. He did not realize that the Agrarians were against giant finance Capitalism of industrialization. See Murphy, "The Failure of a Political Faith in Agrarianism, 1930 - 1940," 68.

${ }^{18}$ Warren in an interview before the Symposium. See Murphy, "Introduction: The rebuke of History," 3.

${ }^{19}$ Karanikas, "Enormous Megatherions," 95.

${ }^{20}$ Ransom, "Reconstructed but Unregenerate," 3.

${ }^{21}$ Karanikas, "Preface," VIII.

${ }^{22}$ Karanikas, "Agrarian Economic Thought," 35.

${ }^{23}$ Quoted by Leonard Unger, ed., Seven Modern American Poets : An-Introduction ( Minneapolis : University of Minnesota Press , 1967 ), 238.

${ }^{24}$ Murphy, "The Failure of a political Faith: Agrarianism, 1930 - 1940" 67. 
${ }^{25}$ Donald Davidson," A Mirror for Artists" in I'll Take My Stand, 46 - 47.

${ }^{26}$ Rubin, "The Poetry of Agrarianism" in Writers of the Modern South : The Faraway

Country ( Seattle: University of Washington Press, 1963 ), 159.

${ }^{27}$ Karanikas, "The Southern Tradition," 64.

${ }^{28}$ Ibid.

${ }^{29}$ Francis Butler Simkins, "The South" in Merrill G. Jensen, ed., Regionalism in America (Madison, WI: The University of Wisconsin Press, 1951), 152.

${ }^{30}$ Karanikas, "The Southern Tradition," 60.

${ }^{31}$ Murphy, "The Failure of a Political Faith: Agrarianism, 1930 - 1940," 72.

32"Statement of Principles," XXIII.

${ }^{33}$ Ibid. , XXV .

${ }^{34}$ I'll Take My Stand, 203.

${ }^{35}$ Karanikas, " From Southern to Agrarian ," 28 -29 .

${ }^{36}$ Karanikas, "The Southern Tradition," 67.

${ }^{37}$ Karanikas, "Agrarian Enormous Thought," 38.

${ }^{38}$ Quoted by Karanikas, "Religion and Myth," 146.

39"Statement of Principles," XV.

${ }^{40}$ Quoted by Murphy," The Failure of a Political Faith: Agrarianism, 1930 - 1940," 56.

41 "Statement of Principles," XXIV.

${ }^{42}$ Daniel Joseph Singal, "The Divided Mind of Allen Tate" in The War Within : From Victorian to Modernist Thought in the South , 1919-1945 (Chapel Hill , NC. , The University of North Carolina Press 1982 ), 233.

${ }^{43}$ Ibid.

${ }^{44}$ Thomas A. Underwood, Allen Tate: Orphan of the South (Princeton: The Princeton University Press, 2001), 4.

${ }^{45}$ Ibid.

${ }^{46}$ Ibid., 3 .

${ }^{47}$ Ibid., 9.

${ }^{48}$ Ibid., 12.

${ }^{49}$ Singal, 232.

${ }^{50}$ Quoted by Karanikas,"From Southern to Agrarian," 20 -21.

${ }^{51}$ Allen Tate, "Preface" to Reason in Madness: Critical Essays (New York: G.P. Putnam, 1941), iv.

${ }^{52}$ Quoted by Murphy "Humanism and Southernism: The Intellectual Origins of Agrarianism," 37.

${ }^{53}$ Quoted by Karanikas, "The Aesthetic of Regionalism," 110.

${ }^{54}$ Quoted by Signal, 347.

${ }^{55}$ Allen Tate, "What is a Traditional Society?" in Essays of Four Decades (London: Oxford University Press, 1970), 556.

${ }^{56}$ Ibid.

${ }^{57}$ Ibid., 555. 
${ }^{58}$ Ibid., 557.

${ }^{59}$ Allen Tate, "The Man of Letters in the Modern World" in Essays of Four Decades, 13.

${ }^{60}$ In "Liberalism and Tradition" Tate describes history as "that quality of life ... that we create and try to pass on to the next generation." See Allen Tate, Reason in Madness : Critical Essays , 207 -208.

${ }^{61}$ Quoted by John M. Grammer, "Reconstructing Southern Literature" in American Literary History 13 (2001): 128. Tate's interest in history is seen in almost all his literary product: poetry, essays, his only novel, The Fathers (1938) and his biographies: Stonewall Jackson : The Good Soldier ( 1928 ) and Jefferson Davis: His Rise and Fall ( 1929 ).

${ }^{62}$ A letter to Fletch (1930) quoted by Murphy, " The Failure of a Political Faith: Agrarianism, 1930 - 1940," 75.

${ }^{63}$ Quoted by Signal, "The Divided Mind of Allen Tate," 247.

${ }^{64}$ Quoted by Bradbury, "Critics and Agrarians," 94.

${ }^{65}$ Ibid., 565 .

${ }^{66}$ Ibid.

${ }^{67}$ Tate, "Religion and the Old South" in Essays of Four Decades, 574, 576.

${ }^{68}$ Ibid., 570.

${ }^{69}$ Ibid., 575.

${ }^{70}$ All line references to Tate's poems are taken from Allen Tate, Collected Poems $1919-1976$ (New York: Farrar Straus Giraux, 1978).

${ }^{71}$ Traditionally an ode publicly celebrates in an external manner an aspect of human existence. Here it is a solitary man grimly reflecting the modernist temper. Tate in his essay "Narcissus as Narcissus, " written on the poem, comments on the title, saying that he first called it an elegy, but then he changed it into an ode, only in an ironic way. See "Narcissus as Narcissus" in Essays of Four Decades, 602.

${ }^{72}$ David Havird, "Allen Tate's life and Career," project: Modern American Poetry [scholarly project on-line], accessed 2 January 2016; available from http://lwww.english.uiuc.edu/maps/poets/s_z/tate/life.htm;_internet.

${ }^{73}$ Quoted in "Narcissus as Narcissus," 599.

${ }^{74}$ Ibid.

${ }^{75}$ In Homer's Iliad, Diomede and Glaucus meet on the battlefield, the former asks the latter who he is, the latter asks about the reason of his question. Glaucus answers those generations of leaves are like that of man. As leaves fall and new ones come out in spring, so one generation passes away another appears. See Iliad, trans. John Halper (New York: Airmont Publishing Company, INC., 1970), 260 -63.

76، Narcissus as Narcissus," 604.

${ }^{77}$ Ibid., $595-596$.

${ }^{78}$ Ibid., 607.

${ }^{79}$ "The Man of Letters in the Modern World," 7.

${ }^{80}$ "Narcissus as Narcissus," 598. 
${ }^{81}$ John L. Stewart, "Allen Tate's Poetry" in The Burden of Time: The Fugitives and Agrarians (Princeton: Princeton University Press, 1965), 384.

${ }^{82}$ "Narcissus as Narcissus," 600.

${ }^{83}$ Ibid., 601.

${ }^{84}$ Stewart, "Allen Tate's Poetry," 391.

${ }^{85}$ Virgil, The Aeneid, trans. John Dryden (New York: Airmont Publishing Company, INC., 1968), 115 -27.

${ }^{86}$ See other poems which deal with the difference between the present and the past: "The Death of Little Boys" ( 1925 ) and "The Last Days of Alice" ( 1931 ).

${ }^{87}$ Murphy," Humanism and Agrarianism: The Intellectual Origins of Agrarianism," 54.

${ }^{88}$ Ibid., 53 .

${ }^{89}$ Ibid., 52.

${ }^{90}$ The Catholic Revival is a movement of intellectuals and clergymen led by Jaques Maritain and Etienne Gilson. It began in Europe late in the fourteenth century and reached its peak in both Europe and The United States in the years between First World War and 1960's. It had its greatest impact in the United States in the forties. Its outlook was medieval, looking to the world before the sixteenth century as a moral, social and intellectual unity. The Revival was aspiring to integrate traditional and modern trends in thought to form an effective human thought to save the Western Civilization from its State of Crisis. It considered the notion of progress an element of cultural disintegration. It was affected by neo - scholasticism which provided it with a philosophy rooted in the unity of spirit and intellect to restore the certainty of God in Western culture. See Murphy "Humanism and Southernism," 36-37.

${ }^{91}$ Dante Alighieri, The Divine Comedy, trans. Dorothy L. Sayers (Harmosworth penguin Books Ltd., 1971), 31 -33.

${ }^{92}$ It is most probably that Tate is referring to Hart Crane who committed suicide.

93،"Inferno," XV.

${ }^{94}$ Unger, 237.

${ }^{95}$ When the poem was first published in 1944, the elements: air, earth, water and fire were the titles of the seasons. See Bradbury, "Tate as poet," 162 and Stewart, "Allen Tate's Poetry," 409.

${ }^{96}$ Louis D. Rubin, Jr., and Robert D. Jacobs, "Allen Tate: The Arrogant Circumstance," 241.

${ }^{97}$ In ancient Greece two roles were assigned to Aphrodite: that of Pandemos (Eros) who was responsible for childbirth and fruitfulness, and Urania ( Agape) who was responsible for heavenly love . See R.K. Meiners, "The End of History: Allen Tate's ' Seasons of the Soul'," The Sewanee Review 70 (January-March 1962): 56.

${ }^{98}$ Ibid., 59

${ }^{99}$ Ibid., $65^{\text {* }}$

${ }^{100}$ Rubin and Jacobs, "Allen Tate: The Arrogant Circumstance," 244.

${ }^{101} \mathrm{Ib}$ 


\section{Bibliograpghy:}

1. Bradbury, John M. The Fugitives: A Critical Account. Chapel Hill: The University of North Carolina Press, 1958.

2. Cowan, Louise. The Fugitive Group. Baton Rouge: Louisiana State University Press, 1959.

3. Dante, Alighieri. The Divine Comedy. Translated by Dorothy L. Sayers. Harmonsworth: Penguin Books Ltd., 1971.

4. Faulkner, Donald W., ed. Exiles' Return : A Literary Odessey of the 1920's. New York: Penguin Books, 1994.

5. Grammar, John M. "Reconstructing Southern Literature." American Literary History 13 (2001): 128.

6. Gray, Richard. American Poetry of the Twentieth Century. South Carolina : University of South Carolina, 1990.

7. --------- Literature of Memory: Modern Writers of the American South.

London: Edward Arnolds (publishers) Ltd., 1977.

8. Havird, David. "Allen Tate's Life and Career." [ Website on-line ]. Available from http: // www. english . uiuc .edu / maps / poets / s_z / tate / life. htm: Internet Accessed 2 January 2016.

9. Hobson, Fred C., Jr. Serpent in Eden : H.L. Mencken and the South . Chapel Hill: The University of North Carolina Press, 1974 .

10. Homer, Iliad. Translated by John Halper. New York: Airmont Publishing Company, 1970.

11. Habbell, Jay B. Who are the Major American Writers ? North Carolina: Duke University Press, 1972.

12. Inge, M. Thomas. Faulkner, Sut and Other Southerners: Essays in Literary History. West Cornwall, ct: Locust Hill Press, 1992.

13. Karanikas, Alexander. Tillers of a Myth : Southern Agrarians as Social and Literary Critics. Madison: The University of Wisconsin Press, 1966.

14. Meiners, R.K. " The End of History: Allen Tate's ' Seasons of the Soul'." The Se Wanee Review 70 (January - March 1962): 56.

15. Meyers, Jack, and David Wojahn. eds. A Profile of Twentieth - Century American Poetry. Carbondale, IL: Southern Illinois University Press, 1991.

16. Murphy, Paul V. The Rebuke of History: The Southern Agrarians and American Conservative Thought. Chapel Hill, NC: The University of North Carolina Press, 2001.

17. Parrington, Vermon Lois. Main Currents in American Thought: An Interpretation of American Literature from the Beginning to 1920. Vol.1. New York : New York University Press, 1975.

18. Rubin, Louis Decimus. Writers of the South: The Faraway Country. Seattle: University of Washington Press, 1963.

19. Rubin, Lois D. Jr., and Robert D. Jacobs .eds. Modern Southern Literature in its Cultural Settings. Westport: Greenwood Press, Publishers, 1976. 
20. Signal, Daniel Joseph. The War Within: From Victorian to Modernist Thought in the South, 1919 - 1945. Chapel Hill, NC: The University of North Carolina Press, 1982.

21. Spiller, Robert E. ed. Time of Harvest American Literature 1910 -1960 . New York : Hill and Wang, 1962 .

22. Stewart, John L. The Burden of Time: The Fugitives and Agrarians. Princeton: Princeton University Press, 1965.

23. Strauss, Walter. Study of Orphic Themes in Modern Poetry. New York Dove Publications , INC. , 1990 .

24. Tate, Allen. Collected Poems 1919 -1917. New York : Farrer Straus Giraux, 1978.

25.

Essays of Four Decades. London: Oxford University Press, 1970 .

26. Reason in Madness: Critical Essays. New York: G.P. Putnam, 1941.

27. Twelve Southerners. I'll Take My Stand: The South and The Agrarian Tradition. Baton Rouge: Louisiana State University Press, 1977.

28. Underwood, Thomas A. Allen Tate: Orphan of the South. Princeton: The Princeton University Press, 2001.

29. Unger, Leonard. ed. Seven Modem American Poets: An Introduction. Minneapolis : University of Minnesota Press , 1967.

30. Untermeyer, Lois. ed. Modern American Poetry and Modern British Poetry. New York: Harcourt, Brace \& World, Inc., 1958.

31. Virgil, The Aeneid, trans. John Dryden .New York: Airmont Publishing Company, INC., 1968.

32. Whicher, George F., ed. Translation Revolt Against Materialism. Boston: D.C. Heath, 1949. 